\title{
ON SIPHONARIA HISPIDA
}

Ey EVELINE and ERNST MARCUS

(with 4 plates)

\section{SYSTEMATIC NOTE}

Hubendick (1946, p. 46) established the correct name for a species of Siphonaria which is evidently common on the Brazilian coast. Sure localities of this species are: Fernando de Noronha (Smith 1890, p. 497; Souza.Lopes \& Alvarenga 1955, p. 179); Bahia (ibid.; Hubendick, 1. c.); Espírito Santo; State of Rio (Souza Lopes \& Alvarenga); northern littoral of the State of São Paulo (present collection). To the last region refer also Ihering's (1915, p. 140) and Lange's (1949, p. 122) indications of $S$. picta d'Orbigny, so that it is probable that also these authors have seen hispida.

By its anatomy Siphonaria hispida Smith, 1890, is defined as belonging to the Subgenus Siphonaria, Section Siphonaria s. str. (Hubendick 1946, p. 44). Beside S. alternata (Say, 1826) it is the only Westatlantic species of this Section, whose numerous other species are Indo-Westpacific. This is a Tethyan distribution, as in many other cases interrupted on the African West coast and in the Mediterranean (Ekman 1935, p. 80 ff., 98-102).

\section{OCCURRENCE AND LIFE}

The locality where we found the species abundant, the Northern Base of the Oceanographic Institute, lies about $14 \mathrm{~km}$ west of Ubatuba $\left(23^{\circ} 27^{\prime} \mathrm{S}\right)$. The snails live on the granitic boulders resting on sand. The surf is seldom strong in front of the Station. The part west of the Station is very sheltered, and the inflow of terrigenous sediments is intense on rainy days. Here Onchidella indolens (Gould) is more frequent than Siphonaria hispida. Also S. pectinata (L.) occurs (G. L. \& N. A. Voss 1955, p. 226) in Biscayne Bay, Florida, in an 
are 1 with little exchange of water. East of the Station where $S$. hispida is more numerous the snails live in the midlittoral zone ( $T$. A. and A. Stephenson 1950, p. 372-376), and occupy higher and lower levels, to a certain degree comparable with the upper and lower yellow zones of the Florida Keys.

The accompanying sessile or semi-sessile fauna of S. hispida is constituted principally of barnacles. Oysters, limpets, and Onchidella are also numerous; littorinids occur higher up. Where the number of oysters increases, also that of their predator, Thais haemastoma (L.) does. On some boulders east of the Station Siphonaria is the widely preponderant element. Drupa (Morula) nodulosa (C. B. Ad.) of the Muricidae Purpurinae was observed preying on Siphonaria. It had drilled the shell, emptied the body cavity, and rasped a hole into the foot when it was disturbed.

At the examined locality of mixed tidal pattern the snails are about as long out of the water as covered. In the highest levels of the habitat big snails are frequent, while middle sized and small ones only occur farther down, as those of $S$. (Benhamina) obliquata (Borland 1950, p. 387). The mantle cavity is open, when the snail is at rest and surrounded by air, at least as long as the air on the rock is damp. We saw that snails taken out of the water open their pneumostome widely and take air into the pallial cavityi. When they are immersed again, a bubble of air is expelled from the anterior, inhalant, part of the pallial opening, or, if they are lowered gradually into the water, one can see the water slowly running along the wall into the mantle cavity to substitute the air. When the lowest level of the tide coincides with a bright day, and the rock becomes dry and hot, the snails are so firmy apposed to the substratum, that we do not think they continue to breathe air during these hours.

In July 1960 we exposed some adult snails to the air in the laboratory. The dish was not exposed to the sun, Ind the temperature varied from 15 to $20^{\circ} \mathrm{C}$. Adhering to a dry slide or fallen down and lying with the sole upwards the animals had their pneumostome constantly open and continued alive for 24 hours. Upon mechanical stimulus they closed the inhalant aperture with the anal lobe, but opened it again after some seconds. On the boulders the uppermost 
snails may perhaps exceptionally be uncovered for a so long time during neap-tides combined with strong wind blowing offshore. When the animals in our experience were returned to the water they released two or three big bubbles of air and voided their excrements. As long as they were exposed to the air they did not move away or defecate.

Parts of the body most exposed to desiccation are mantle skirt, head, and upper surface of pedal border, because the edge of the shell does not fit quite tightly into all the unevennesses of the rock surface. The secretion of the big glands $(\mathrm{g})$, well figured by Fretter and Graham (1954, f. 8), may protect these zones against drying out. The proportionally larger surface of a small snail loses much more water than that of a big one, and probably therefore the small snails are restricted to lower levels.

The animals crawl and feed while they are covered by water and also out of it, as long as the rock is wet. Uncovered Onchidella indolens is active longer than Siphonaria hispida; but the pulmonate remains uncovered for a longer time.

After browsing $S$. hispida generally returns to the place where it has settled, like S. alternata. S. (Benhamina) obliquata, and others (Hubendick 1947, p. 63; Borland 1950, p. 388). This is evidenced by the exact conformity between the outline of the shell with each of its peripherally projecting ribs and the contour left on the boulder. This was already observed by Boettger (1933, p. 343: also references to Patella and Crepidula). On an empty oyster shell with green algae in a dish a snail cleans its place in few hours by feeding. Uncovered the animals adhere as firmly to the rock as resting snails under water; true limpets cling much faster. Snails that fall upside down try to right themselves bending their head downwards.

The egg strings, similar to those of Amphibola crenata (Farnie 1924 , f. 1), were found all the year round. They are $2 \mathrm{~cm}$ long, 4 mm thick, curved (Fig. 1), often forming a complete circle, and contain about 2.000 egg capsules with one egg each. In transverse section the string is as high as broad; it is attached to the rock with a plane underside (Fig. 2). The strings are fastened to the bare boulder, not in water-filled concavities ("cuvettes") as does $S$. atra (Risbec 1935, p. 414). At first the strings are colourless with ivory 
eggs, after some days they become yellow and later on greenish by growing algae. The eggs are poor in yolk. The embryo has a big, bilobed velum (Fig. 3, ve), more prominent than that of Amphibola crenata, and a large transparent operculum (ou) which stands out over the foot as in S. atra (Risbec, l. c.).

The embryonic shell $(\mathrm{s})$ is yellow and similar to that of Otina (Morton 1955a, f. 12), in that the first half whorl is at right angles to the rest of the apical bulb which has a dextral direction. Reduced heterostrophy occurs in several archaeopulmonates (Harry 1951, p. 13). As a character not subjected to adaptive influence this reduced heterostrophy, according to Morton (1955b, p. 151, 161), indicates a phyletic relation between basal cephalaspids and pulmonates. The larval shell of $S$. hispida has not quite one and a half whorls. In the hatching veliger the shell is 300-340 $\mu$ long, $200 \mu$ broad. Embryonic malformations are frequent in the egg strings, especially unrolled shells, similar to those that Risbec described (1935, p. 414) and figured.

The hatching stage is ambivalent swimming-crawling, but while swimming it remains near the bottom of the dish. The eyes and the foot grow gradually; the foot is at first developed posteriorly, and its fore end enlarges later. The velum decreases, but is still ciliated on the third day of free life. On the fourth day, the last of our metamorphosing animal's life, the velum was reduced to unciliated knobs; the eyes were big; the foot was prominent in front and behind, and was the only organ of locomotion. However, movement was not accomplished in the definitive manner of even gliding, but by jerks, the stretched anterior border of the foot fixed itself and drew the body with the larval shell forward. The operculum was still present. Free-swimming veligers were described for $S$. (Benhamina) obliquata (Borland 1950, p. 391).

Like in most species of Siphonaria (Hubendick 1947, p. 63-64) the larva of $S$. hispida is not pelagic. Nevertheless it can be a means for gradual dispersal of the species. As many gastropod larvae can postpone their final settlement (Morton 1958, p. 143), even broad barriers, as sandy or muddy shores, can occasionally be overcome. For example the jetties on the coast of Texas were colonized in the last 50 years by $S$. (Patellopsis) pectinata (Hedgpeth 1953, p. 189). 


\section{SHELL}

The shell is, in Hubendick's terms (1946, p. 7), small (under $15 \mathrm{~mm}$ ) to medium large $(15-30 \mathrm{~mm})$, and low to medium high, that is, higher than one fourth of the length but not more than half the length. Among 500 of our shells the length varies from 2 (youngest found snails) to $20 \mathrm{~mm}$. The last shell is $17 \mathrm{~mm}$ broad, so that its ratio of length to breadth is $1,25: 1$. This ratio varies from 1,06 to $1,50: 1$.

In our youngest, $2 \mathrm{~mm}$ long shells the apex occupies a distinctly posterior position. By later growth of the posterior ribs of the shell (Fig. 4) it is removed forward. Also in adult shells (Fig. 5) the apex lies a little to the rear. The upper side of the shell has 9-20 dominant white ribs, one or two over the siphon. Between the dominant ribs there are smaller ones or only a radial striation. The interspaces between the ribs are dark brown or black. Generally the dominant ribs project over the margin. The circumference is irregular, especially on the right side and behind. The colour of the underside is dark brown is living snails; the furrows corresponding to the ribs are white. The smooth centre occupies from one sixth to one half of the shell breadth, and its colour varies from brown over yellow and grey to greenish.

The narrow outermost part of the apex is bent backwards (Fig. 5 ). On its under surface the protoconch is exceptionally preserved.

The upper side of the shells, even of quite young ones, is densely covered with a felt of algae and sometimes fungi. On the larger shells there are often tufts of Enteromorpha or other leaf-shaped algae, small barnacles, oysters, and mussels.

\section{EXTERNAL CHARACTERS}

Corresponding to the dark furrows between the light ribs of the shell (Fig. 6, 7, s) the mantle skirt (ms) is pigmented with black. Round, frequently confluent black spots occur on the head and the upper surface of the foot. Two folds (ce) which begin on the sides of the head unite over the mouth (mo). Their anterior border is richly innervated and bears sensory cells; laterally the folds contain the subepithelial eyes. These oral lobes (Simroth 1909, p. 89) or 
sensory head lobes (Borland 1950, p. 387) constitute what is called a frontal veil in opisthobranchs. The conspicuous cephalic lobes of I rimusculus (Gadinia) (Schumann 1911, p. 4) and the small tentacles of Chilina (Haeckel 1911, p. 95) correspond to the cephalic folds of Siphonaria.

Hidden in the deep furrow between head and foot (f) lies a pair of small white folds (Fig. 6, x). Their epithelium contains sensory cells and is underlain by nerve fibres, but these were not found converging to a common nerve, as such are distinct in the cephalic lobes and under the sensory epithelium of the anterior border of the foot. Topographically the much bigger labial palps of Chilina (Haeckel 1911, p. 94-95) can be compared with these sense organs of Siphonaria hispida, which are also very similar to those of Philine (Brown 1934, f. 5, 21, pa).

In many of the narcotized snails the walls of the buccal tube are everted, so that the unpaired jaw (Fig. 8, j) appears over the vertical mouth slit. Between head and mantle skirt is a deep furrow which ends a certain distance in front of the shell adductor. The latter's fore ends are united by muscles which irradiate into head and mantle skirt. Also dorsally to the respiratory opening muscle fibres bridge over this gap of the adductor. The pluricellular glands (Fig. 11, g) whose secretion may be repugnatorial (Fretter and Graham 1954, p. 578) or protective against desiccation are numerous on the front of the head, the upper surface of the foot, and the underside of the anal lobe (az). Unicellular, deeply insunk mucus glands are scattered over the sole, more numerous in front. but not concentrated.

\section{PALLIAL ORGANS}

Hubendick's proportion between width of pallial opening and body length (1947, p. 38, 88) was not found in $S$. hispida. In adult $14,5-15,5 \mathrm{~mm}$ long snails, preserved and removed from the shell, the width of this opening is $20 \%-39 \%$. Nearly the same extremes, $22 \%-40 \%$, occur in 4,5 and $5 \mathrm{~mm}$ long animals. As in other limpet-like gastropods the pneumostome is rich in glands (Graham in Morton 1955a, p. 116). The anal lobe (Köhler 1893, p. 3), inferior fallial or respiratory lobe (Pelseneer 1894, p. 73, 81), or siphon 
(Hubendick 1947; Yonge 1952), is actually a modified anal papilla, provided with longitudinal muscles. It is tripartite as is a similar cutaneous appendage of Viviparus and Planorbis (Simroth 1876, pl. 20 , f. $20-22$, b) . The pallial walls are more or less pigmented, except over the gill, where the roof is white. In a $15 \mathrm{~mm}$ long and $11 \mathrm{~mm}$ broad snail the pallial cavity is $7 \mathrm{~mm}$ long. Backwards it does not attain the adductor.

Along the posterior margin of the gill runs the dorsal ciliated ridge, and below this, on the floor of the pallial cavity, the higher ventral ridge (ci). These organs were well described by Köhler (1893, p. 5, 55), whose figures 38 and 39 'show their continuity on the left side behind the pericardium.

In his postscript (p. 84) Köhler homologized them with the ci.iated ridges in the Cephalaspidea. Among the opisthobranchs they are also known from the Pyramidellidae (Fretter and Graham 1949, p. 499) and young Anaspidea (E. and E. Marcus 1957, p. 11), among the pulmonates from Chilina, Latia, and Amphibola (Haeckel 1911, p. 100-101). Perrier and Fischer (1909) called the ridges "raphé supérieur" and "raphé inférieur". Théy understood (1910), as already Pelseneer (1894, p. 14) had, the respiratory function of these ridges. In Siphonaria hispida their cilia beat towards the exhalant opening (ne) of the siphon and so draw a compensating inhalant flow between the branchial lamellae. The cilia of the gill are too sparce in Siphonaria to have much effect on the flow of the water (Yonge 1952, p. 194). It is of high morphological interest to see how the pallial cavity diminishes inwards, where the ridges pass into one another. Here its wall even forms a short diverticulum, a very small pallial caecum, fixed with a bundle of the adductor muscle. Also Chilina and Latia have a caecum. As in Acteon (Fretter and Graham 1954, p. 568) a blood space (Fig. 10, am), partly with own walls, lies between the mantle (ia) and the dorsal ridge of Siphonaria.

The rejection of sediment carried into the pallial cavity with the respiratory current was described by Yorige (1952, p. 195 ff.). It does not work very efficiently at the place where we found our snails. In the shallow bay in front of the boulders the bottom is sand and mud, so that even the generally light surf carries sediments at 
every flood tide. Not all, but many of our dissected specimens had a surprising amount of sand grains within their pallial cavity. Possibly they can get rid of them from time to time by muscular action as Patella does (Yonge 1947, p. 471).

The osphradium curves around the hind surface of the right anterior pillar of the adductor. While it is furrowed longitudinally in the species examined by Hubendick (1947, p. 192), it is even in $S$. hispida. The histological limit between middle and sides is sharp. The columnar cells in the middle are unciliate and contain brown pigment. To the sides the cells are ciliate, but the cilia are low, shorter than in Hubendick's figure 107. The sensory cells of the two lateral bands are connected with the osphradial ganglion by bundles of fibres with nerve cells between them .

The kidney (k) belongs to Hubendick's type c (1947, p. 35). The nephropore (rv) goes out from the 'outer part of the dorsal lobe, the reno-pericardial duct from the inner. Covering the surface of the pericardium ( $r$ ) the ventral lobe of the kidney extends onto the floor of the mantle cavity. The ventral portion is smaller than the dorsal one, which is prolonged anteriorly beyond the efferent vein (ev) of the right part of the gill (b). This vein receives also vessels (vr) from the anterior part of the roof of the mantle cavity. This vascular net is generally called pulmonary (Hubendick 1947, p. 95 ), in the presupposition that the snails are air-breathing during low tide, e. g. Hutton (1882, p. 342-343); Pelseneer (1894, p. 81; 1895); Plate (1894, quoted from Simroth and Hoffmann 1927, p. 983); Cooke (1895, p. 151); and Cottrell (1911, p. 593).

Yonge $(1952$, p. $198 ; 1958$, p. 36$)$ thought that aerial respiration is improbable in Siphonaria alternata. In $S$. hispida, however, we observed, as mentioned above, the intake of air into the mantle cavity, when the snails are out of the water. In this species the pallial cavity has the same dual'function of a lung and of a branchial chamber that was verified by Yonge $(1958$, p. 35) in Trimusculus reticulatus (Sowerby). Our species lives higher on the shore than $T$. reticulatus which occurs only if well protected in a damp atmosphere.

In a without shell $2,2 \mathrm{~mm}$ long Siphonaria (Kerguelenia) lateralis Köhler (1893, p. 29) found the left part of the gill incom- 
pletely developed with no efferent branchio-renal vessel. The adult snails of this species are $16 \mathrm{~mm}$ long. An 1,8 mm long animal of S. (S.) hispida had this vessel and a gill (b) whose left part was only less folded than the right. In large snails right and left branchial portion have equal structure and correspond to the plicate type of tectibranchs. Whether such branchiae can be derived from pectinate ctenidia with filaments is an open question. Köhler (1893) anci Gilchrist (1894) whose views are reported by Hoffmann (1940, p. 14-16) and Hubendick (p. 120) consider plicate and pectinate gills as modifications of a common primordium; Yonge (1947, p. 498; 1952, p. 197-198) stresses the differences.

The afferent renal vessel of the tectibranchs originates from the afferent branchial vessel. Topographically it corresponds to the anterior afferent renal vessl (ra) in Siphonaria. The posterior afferent renal vessel (or) of Siphonaria has no counterpart in tectibranchs. The efferent renal vessel of tectibranchs opens into the auricle together with the left or inner efferent branchial vessel; in Siphonaria it (nv) opens farther to the right into the efferent branchial vessel (vz). Therefore Hubendick considers the left part of the gill of Siphonaria, from the anterior afferent renal vessel inwards, as secondary and not comparable to the gill of tectibranchs. But as the entire gill of Siphonaria has one and the same structure and only shows slight differences in its development, we think it is homologous with the cephalaspidean gill and compare the two efferent branchial vessels (ev, vz) with the corresponding ones of the Cephalaspidea .

As Köhler observed (1893, p. 77) a muscle (mx) extends from the auricle (rc) into the principal branchial vein (ev). Hubendick (1947, p. 41, 95, 110) found one or two such muscles in Siphonaria, Williamia, and Amphibola, not in Gadinia and Chilina. 'Köhler's phylogenetic interpretation of this muscle was not accepted by Hubendick (p. 170). Possibly the heart is distended by the contraction of this muscle and circulation accelerated by its action .

\section{CENTRAL NERVOUS SYSTEM (Fig. 13)}

The cerebral ganglia ( $\mathrm{cn}$ ) lie ventrally to the oesophagus and are united by a long commissure which runs dorsally over the oesophagus . There is no subcerebral commissure. Hubendick (1947, p. 101) was 
the first to find the lateral lobes (Fig. 12, xo) in sections of Siphonaria. They are more lateral than in Trimusculus (Gadinia) (Schumann 1911, p. 53-54). In young snails of $S$. hispida the cerebral tute; (t) which originate the lateral lobes of the cerebral ganglia are connected with the epidermis. On the right side the cerebral tube begins at the genital aperture (Fig. 21). These primordia pass through the thick body musculature as epithelial tubes (Fig. 12, t). They begin with a diameter of $20 \mu$, diminish abruptly to $6 \mu$ half way through the muscular wall, and pass into the cavity of the head, where they run backwards to the brain. Here the tube becomes thicker and solid by increase of the size of its cells. A lumen between these cells was not seen, even in our smallest specimens, and in full grown snails also the cerebral tubes could no longer be distinguished, contrary to Trimusculus peruvianus and garnoti. The membrane of the cerebral capsule is interrupted between lobe and ganglion by several tracts of nerve fibres .

The buccal ganglia lie on the pharynx under the beginning of the oesophagus, and correspondingly the cerebro-buccal connectives are rather long. The length of the buccal commissure approximately equals the diameter of one of the ganglia.

In correlation with the importance of the foot as fastening organ the pedal ganglia (q) are voluminous, as big as the cerebral ones. The pedal ganglia lie behind the cerebral ganglia and a little farther ventral. The cerebro-pedal connectives are short but distinct. The statocysts (so) lie under the lateral surface of the pedal ganglia. There are two pedal connexions, the thick anterior pedal commissure and the thin posterior, still longer parapedal one. The genital nerve (na) goes out from the right pedal ganglion, accompanics the cerebro-pedal connective and becomes gradually independent from it. Perhaps therefore Dieuzeide (1935, quoted from Hubendick 1947, p. 91) indicated a cerebral innervation of the genital atrium, while Köhler (1893, p. 20) observed the origin of the genital nerve (f. 9, ng) correctly.

A big ganglion (wu) constitutes the root of the visceral loop on the left side. It is connected with the cerebral and the pedal ganglion by short connectives. As in the species examined by Hubendick (1947, p. 117) three nerves go out from this ganglion, two anterior ones to the left, and one which bifurcates soon after its origin, to the adductor. 
One of the anterior nerves supplies the mantle skirt. By its nerves this ganglion is characterized as pleuro-parietal ganglion.

The corresponding right ganglion (eu) is small, simple, and without nerves. It is apposed to the right cerebral ganglion, while its connective to the pedal ganglion is distinct. It is a pleural ganglion. Though always much smaller than the left pleuro-parietal ganglion its size varies individually. In some snails there are only some nerve cells corresponding to the right pleural ganglion at the root of the pleuro-pedal connective. Cottrell's figure of the central nervous system of $S$. (Benhamina) obliquata (1911, f. 5) also shows two ganglia on the right side, but the anterior (proximal) is bigger than the posterior (distal) one.

Köhler (1893) and Hubendick (1947) found ganglia of equal quality on both sides of the visceral loop; Köhler called them pleurointestinal, Hubendick pleuro-parietal gang.ia. As there are two separate ganglia on the right root in $S$. hispida, the name of the posterior one will in the following be proposed in conformity with its nerves and with the nature of the neighbouring ganglia.

We agree with Hubendick (1947, p. 115-116) who does not consider Köh!er's qualification "abdominal" ganglion as sufficient for the sing? ganglion (as) of the visceral loop in Siphonaria. Its at least four nerves supply not only the ental (proximal) reproductive organs but also adductor, kidney, pericardium, siphon, and rectum. Hence this ganglion must be understood as a coalesced abdominalsubintestinal ganglion. As in the other species of the Siphonaria (Siphonaria) sipho-group (Hubendick 1947, p. 40) this ganglion lies nearly straight to the right of the nerve ring. A short connective connects it with the next right ganglion (zr).

This is a big ganglion and emits two nerves. One of them runs to the right body wall. The other supplies the border of the mantle and the osphradium. The osphradial branch is sometimes so short that the osphradial ganglion (zo) is almost continuous with the central ganglion. According to Hubendick's point of view this ganglion should be called right parietal ganglion. Hubendick (1947, f. 106) adopts the zygosis theory (Krull 1934) as best explanation for the phyletic origin of the central nervous system in the Pulmonata. This theory postulates a loss of the supra-intestinal portion of the visceral loop 
including the ganglion. Consequently the innervation of the osphradium would have passed from the supra-intestinal to the parietal ganglion, or the osphradium of these "basically primitive" (Morton 1955b, p. 163) pulmonata must be considered as a novelty, heterologous with that of the Cephalaspidea. A discussion of the theories concerned with the evolution of the central nervous system in the Pulmonata lies beyond the limits of the present paper. In Siphonaria we suppose a dislocation of the left-sided osphradium of Acteon towards the right as in Chilina. Therefore we call the centre in question "parieto-supraintestinal" ganglion, as it was named in some species of Chilina (Haeckel 1911 , p. 127, f. 38,46 ).

\section{ALIMENTARY TRACT (Figs. 16, 17)}

The radula (Figs. 14, 15) was examined in 25 snails. It comprises about 120 rows of $18-34.1 .18-34$ teeth. The rows are procoelous, i. e. concave in front. The minimum, 18 lateral teeth, refers to a 3 $\mathrm{mm}$ long animal. An outer denticle (ectocone) may appear already on the first lateral tooth, or on one of the following, once even on the 8th, independently from the size of the snails. Malformations generally extend over an entire longitudinal row, e. g. coalescence of 2 neighbouring teeth. On the whole the radula is rather multiform. The rhachidian tooth is narrow and bears a single cusp. The inner lateral teeth have a bicuspidate edge and the outer denticle. From about the 11th tooth outwards an inner denticle (entocone) appears, and the two principal cusps (mesocones) coalesce to a rectangular plate. In the lateral region of the radula there are two outer denticles. The outermost (marginal) teeth are low and simplified. The various regions of the radula pass gradually from one type of teeth to the next.

Alive the pharynx is dark red, perhaps due to haemoglobin, as frequently pharyngeal and radular muscles are, which need much oxygen (Pelseneer 1935, p. 156; Ankel 1936, p. 124).

The flattened salivary glands are composed of branched white tubes with a narrow lumen joined to a wider duct which opens dorsolaterally into the pharyngeal cavity. In this region the dorsal wall of the alimentary channel assumes its folded oesophageal character. A little farther behind the brown oesophagus is already closed, and also 
its ventral wall is folded. Here the buccal ganglia lie between the floor of the oesophagus and the pharyngeal bulb. Clusters of blue staining gland cells open into the ventral wall of the anterior oesophagus. The median buccal gland of Otina otis (Morton 1955a, p. 122 , f. $5 \mathrm{~A}, \mathrm{~m} \mathrm{bg}$ ) lies dorsal and does not open into the oesophagus, so that it is not comparable with the present structure.

The oesophagus (o) goes out from the dorsal side of the pharyngeal cavity near the middle of its length, hence relatively far in front. Its low epithelium and slight longitudinal folds become gradually taller and stronger (eo) backwards, where blue staining glands open on the crest of the folds. The epithelial cells contain brown pigment. Already in the oesophagus the algal particles scraped off from the rock by the radula are pasted together to a mucous food string (os). When stuffed with food, nearly the entire gut, viz. oesophagus behind nerve ring, stomach (sm), intestine (i), and rectum (re) are distended to smooth-walled sacs .

As in cephalaspids and pulmonates (Graham 1949, p. 755; Fretter and Graham 1954, p. 582) oesophagus and intestinal gastric apertures are approached to one another (Fig. 16). A tubular, not saccate, stomach, whose oesophageal and intestinal apertures lie on opposite ends (Hubendick 1947, f. 67, 68), is only obtained by wrenching off the hepatic appendages. There are 3 lobulate anterior digestive diverticula, two dorsal (1) and one ventral (ni). They communicate with the stomach by the corresponding dorsal (aa) and ventral (av) openings. As the liver ducts branch immediately at their roots, they appear to have subsidiary apertures as Patella vulgata (Graham, 1949, f. 23).

A broad fold (vm) connects the anterior ventral liver aperture with the opening (ao) of the posterior digestive diverticulum (um). The position of the posterior aperture in the middle of the gastric fundus (or apex) is a primitive character (Morton 1955h f. 3A, 3B). The fold is continuous with the major typhlosole $(y)$ and is a landmark in the ventro-median line of the stomach. It approximately separates a ciliated right from a cuticulate left (cu) zone of the stomach.

The pigmented epithelium and the high folds (eo) of the posterior oesophagus end abruptly at the entrance into the stomach. The 
ciliated part receives the food string (os), and here the latter forms a compact mass (oo) in living and preserved snails. Thence the string is continued backwards, curves to the left, and is drawn forward again into the intestine by the protostyle (ro) .

The fundus of the stomach is coated with a silky transverse muscle layer and fewer longitudinal fibres. By the contraction of these muscles a terminal pocket (mu) may be jutted out which disappears when the muscles relax. This pocket is comparable to the "gizzard of the simplest form" in Otina otis (Morton 1955a, p. 126). The apical musculature is continuous with that of the cuticularized area $(\mathrm{cu})$. This rather strong development of gastric musculature is a pulmonate feature.

Dense folds occur around the apertures of the anterior digestive diverticula and enter them. About 8 short longitudinal folds (sa) converge on the quite narrow intestinal groove (io) which is bounded by the typhlosoles $(y$, in). The folds are densely ciliated and constitute a posterior sorting area. Beside the groove lies the "style sac", a longitudinally folded zone lodging the protostyle (ro). The latter is continuous with the food string (os) as well as with the faecal rod (er) in living and preserved snails.

Cilia and peristalsis carry the faecal rod through the intestine (i). The two intestinal loops correspond to the type known in the subgenera Siphonaria (Hubendick 1947, f. 66) and Patellopsis (Köhler 1893 , f. A). The cephalic artery (wa) whose wall contains black pigment passes through the first loop (Fig. 17). The rectum is coated with thick annular muscles. Their action discharges long faecal strings. As Yonge (1952, p. 196) observed in Siphonaria alternata, the anus opens and closes frequently. This activity is independent from releasing and nipping off a faecal pellet.

In sections of a $5 \mathrm{~mm}$ long snail we found a radula with incompletely digested musculature in the region where the protostyle passes into the faecal rod. The radula may have been that of a young $S$ hispida .

Young snails as well as hungry ones are darker than those well nourished. 


\section{REPRODUCTIVE ORGANS}

The generative organs (Fig. 18) of an adult snail with full-grown ovosytes are characterized by an orange gonad (wn) and light orange glands (we, me) of the spermoviduct. The ovocytes are $150 \mu$ in diameter, their nuclei $60 \mu$. The small ovotestis lies under the stomach between the digestive diverticula in the body cavity. The species is protandruus, but male and female phases are not separated. Spermatogenesis is never completely interrupted. Egg laying is followed by more intense production of sperm. The snails evidently live for more than one year, as Borland (1950) observed in S. obliquata. In the lobules of the hermaphrodite gland the male germ cells are central, the female ones peripheral.

The slightly pigmented ciliate hermaphrodite duct $(h)$ is either principally straight or more coiled. Ectally it is somewhat dilated into a longish ampulla containing sperm. The so-called seminal vesicle distally to this ampulla might function as seminal receptacle (rs) (Simroth 1912 , p. 491) and fertilization chamber.

Thence the spermoviduct becomes glandular, much convoluted, and sacculate. Its inner course is called albumen gland (we), the outer one mucus gland (me). In the latter a spermoviducal fold begins which separates a ciliate seminal and a glandular oviducal groove. Ectally to the mucus gland portion the spermoviduct (vi) rises and runs quite near the floor of the mantle cavity. Its fold disappears gradually and is substituted by longitudinal folds of a ciliate epithelium. The wall of the duct is strongly muscular and it passes through the right anterior pillar of the adductor. Before the duct enters the common atrium, it forms a dorsal glandular pouch (is). The spermoviduct (vi) opens inside the genital aperture ( $\mathrm{z}$ ) and at a certain distance from it .

Immediately beside the spermoviducal opening lies that of the bursa whose long duct (ur) is parallel to the spermoviduct. As in most species of the section Siphonaria (s. str.) it runs through the adductor near its outer edge (Hubendick's figure 63b). The retractor (e) of the bursal canal is contracted in some of our specimens, relaxed in others. Correspondingly the duct is distended into a loop close to the epiphallus (d) or not. Hence an extension of the bursal canal in front 
of the epiphallus seems not to be a systematic character (Hubendick 1947, p. 30).

Farther inwards than bursa and spermoviduct the epiphallus duct (d) and the male copulatory organ (p), Hubendick's "muskulöse Scheide", enter the common genital outlet. The epiphallus duct becomes gradually thinner in its ental portion and ends with the flagellum (ae). Conspicuous glandular sacculations of the duct, the epiphallus gland (ze) or prostate, are in many species known to secrete the spermatophores. We did however not find any spermatophore in more than 50 mature animals examined in all seasons.

The copulatory organ $(\mathrm{p})$, also provided with a retractor (e), is 1,05 to $0,77 \mathrm{~mm}$ in transverse sections of the invaginated phase and 2,5 $\mathrm{mm}$ long. The corresponding measurements of eraginated stages are 3,0 to $1,4 \mathrm{~mm}$, and $7 \mathrm{~mm}$. The organ is distended by liquid of the body cavity, and therewith its size increases enormously (Fig. 19). Its outward movement turns the entire common atrium inside out (Fig. 20). Epiphallic (ma), spermoviducal (ea) and bursal (ua) openings are separated in this condition; the epiphallus duct debouches at the root of the evaginated penis.

In one specimen Hubendick (1947, p. 9) observed a bipartite penis of $S$. elegans. This case may be explainable as an incomplete evagination.

\section{DEVELOPMENTAL STAGES OF REPRODUCTIVE ORGANS}

In without shell $1,8 \mathrm{~mm}$ long snails, the smallest we found, a 1,03 $\mathrm{mm}$ long common primordium of genital organs (Fig. 21) extends uninterrupted from the single aperture $(z)$ inwards. The copulatory organ is not developed yet, nor the bursa canal. The epiphallus gland (ze) is already indicated by a thickening with a fold of high epithelium on either side of the lumen. Contrary to what Hubendick (1947, p. 32 ) expected, the development of the epiphallus duct precedes that of the bursa. The tubular spermoviduct (vi) is continuous with the incipient thickening of the glandular duct (w). The latter is connected with the ovotestis (wm) by the strand of the future hermaphrodite duct $(h)$.

In the next, without shell $2 \mathrm{~mm}$ long snails a thin primordium of the bursa canal (Fig. 22, ur) appears. With a body length of $2,7 \mathrm{~mm}$ 
the genital primordium from aperture to gonad is comparable with Köhler's developmental stage of a 2,2 mm long specimen (1893, p. 34, fig. D) . Hubendick's stage $(1947$, f. 83 ) is more advanced. Köhler figured the opening of the epiphallus and the distal end of the spermoviduct not connected, but said (p. 33) that this separation could not be verified with certainty. As in his species $S$. (Kerguelenia) lateralis the spermoviduct of the adult opens into the outermost part of the common atrium (Hubendick 1947, f. 15), one can hardly infer from Köhler's single specimen that epiphallus and spermoviduct develop separately .

In a $3 \mathrm{~mm}$ long snail the glands of the spermoviduct begin to become differentiated; in a $4 \mathrm{~mm}$ long animal duct, gland and flagellum of the epiphallus are defined. In a snail of $5 \mathrm{~mm}$ the copulatory organ begins to grow out and sperms are accumulated in the hermaphrodite duct. The first quite small ovocytes were seen in a 7 $\mathrm{mm}$ long snail whose copulatory organ is well developed.

The indications of the lengths give merely an approach to the successive developmental stages, as sometimes snails of equal size are in different phases of their reproductive organs.

\section{CONCLUSIONS}

Siphonaria hispida belongs to the subgenus Siphonaria Hubendick (1946, p. 35), section Siphonaria s. str. (ibid., p. 44; 1947, p. 29-32). This section is the highest developed group of the genus (1947, p. 52, 75, 83).

The Siphonariidae are not wholly primitive nor geologically old, The oldest finds are Cretaceous (p. 74, 16: Anisomyon). The Silurian and Devonian Hercyonella to which Morton (1955b, p. 165) evidently alludes is not a sure siphonariid (Hubendick 1947, p. 76) .

The following evaluation of primitive and specialized characters of Siphonaria is orientated by Hubendick's (1947, f. 105) and Morton's (1955b, f. 15) diagrams. The first shows two principal basommatophorous branches gradually diverging from a common root. One of these comprises Ellobiidae and Otinidae and gives origin to the Stylommatophora. The second comprehends Patelliformia (Siphonariidae, Trimusculidae), Amphibolidae, Chilinidae and Latiidae as more ancestral, and Thiele's (1931) families 3-6 as more advanced 
groups. Morton's figure corresponds to Fretter's and Graham's concept (1954, p. 582-583) of the relationship of Prosobranchia, Opisthobranchia, and Pulmonata. The two latter originated side by side from the Trochacea, viz. unibranchiate archaeogastropods; the mesogastropods and their descendants, the neogastropods, from the same stock, but apart from the two other subclasses. Cox (1960, p. 246) suggests to consider Mesogastropoda and Neogastropoda as a single order, Caenogastropoda.

Primitive characters of Siphonaria are: larvae with big velum and operculum, cephalaspidean gill, osphradium immediately inside the pallial opening, ciliated pallial ridges, and pallial caecum. It the stomoch primitive characters predominate. There is no pulmonate gizzard (e. g., Carriker 1946, p. 53, f. 17 on p. 30). The muscular pocket (Morton 1955a, f. 7, mp), a primordial gizzard, is inconstant. Anterior and posterior digestive diverticula remain in their primitive positions. A posterior sorting area, though small, an intestinal groove, though narrow, and a style sac with protostyle are developed. In a quite primitive stomach a posterior caecum might be expected, but this is absent.

Specialized characters of Siphonaria are: the short visceral hump with a correspondingly limpet-like shell, the absence of a hypobranchial gland which occurs in Acteon and the Ellobiidae, the spermatophores, the opening of the epiphallus together with spermoviduct and bursa, and in comparison with Acteon the radula. The nervous system of Chilina (Pelseneer 1894, f. 210; Haeckel 1911, pl. 10, f. 38; Hubendick 1947, f. 100a, b), Amphibola (Farnie 1919, p. 78, f. 5; Bargmann 1930, pl. 1, f. 5; Hubendick 1947, f. 88), and primitive ellobiids as Pythia (Plate 1897, p. 122-123) and Ovatella (Pelseneer 1894, f. 205) is less concentrated and has a much longer visceral loop than that of Siphonaria with short connectives, coalesced left, sometimes also right, pleural and parietal ganglia and only one "synthetic" (Hubendick 1947, p. 116) ganglion in the short visceral loop .

Yonge (1952, p. 196) and Morton (1955a, p. 148; 1958, p. $75)$ consider the Siphonariidae as derived from terrestrial pulmonates and re-adapted to submerged life. This opinion is the consequence of placing the Ellobiidae at the root of the pulmonates as archaeopul- 
monata (Morton 1955b, p. 163) "par excellence", "acteonids of the pulmonates" (p. 160). The spermatophores of Siphonaria do not necessarily indicate a terrestrial origin; this advanced type of sperm transmission may as well have originated during aquatic life. We do not approach, as Boettger (1954, p. 267 , f. 1) did, the Siphonariidae more to the basis of the Pulmonata than the Ellobiidae, but point to signs of a primary aquatic life in Hubendick's second branch of the Basommatophora to which Siphonaria belongs. Such are: the freeswimming veligers of certain species, gill, osphradium, pallial ridges, and renal pore within the mantle cavity. A new acquisition of these characters by originally terrestrial snails, especially the larvae, is hard to be imagined. A monophyletic origin of the Pulmonata is not questioned, if one assumes that the appearance of a lung in the marine ancestors enabled their descendants to breathe air periodically or constantly.

\section{RESUMO}

Da Ilha Fernando de Noronha até o litoral de São Paulo (aí como picta d'Orb.) conhece-se Siphonaria hispida Smith, 1890, pulmonado pateliforme com brânquia. Pertence à sěcção Siphonaria (s. str.) da qual é a 2a. espécie atlântica. Vive nas rochas, na zona das marés, raspa algas enquanto está coberta pela água e retorna ao lugar ocupado durante a vasante. Do ovo (Fig. 3) sai veliger com opérculo (ou); a concha larval (s) é ligeiramente heterostrófica.

Lóbulos cefálicos (ce), pequenas dobras ( $\mathrm{x}$ ), e bordo anterior do pé (f) são sensoriais. Na cavidade palial, os cílios das crestas dorsal e ventral (ci) produzem entrada e saída dágua. Nesta cavidade, abre-se o poro (rv) do rim (k). A brânquia dobrada (b) corresponde à dos Cephalaspidea. O osfrádio situa-se internamente ao orifício inalante (no); seu gânglio (zo) está ligado a um gânglio (zr) na raiz direita da alça visceral. Êste gânglio, separado do pequeno gânglio pleural direito (eu), chamamos de parietó-supra-intestinal.

A rádula (Fig. 15) é mais diferenciada que a de Acteon. Glândulas unicelulares desembocam na parede ventral do esôfago anterior. O estômago $(\mathrm{sm})$.comunica-se com 3 divertículos digestivos anteriores, 2 dorsais (l) e 1 ventral (ni), e com 1 posterior (um). Pequena área escolhedora (sa), estreito sulco intestinal (io), e pro- 
tostilo (ro) ocorrem no estômago; ceco posterior, não. O alimento já se forma em cordão (os) no esôfago, passa ao ptotostilo e, daí, ao cordão fecal .

A espécie é proterândrica, mas não há fases sexualmente separadas. O órgão copulador ( $\mathrm{p}$ ) evaginável pelo líquido do corpo aumenta de 2,5 a $7 \mathrm{~mm}$ de comprimento quando evertido (Figs. 7, 19). Espermatóforos não foram encontrados em mais de 50 animais maduros examinados; possivelmente não ocorrem em $S$. hispida.

\section{REFERENCES}

Bargmann, Helene E. 1930, The morphology of the central nervous system in the Gastropoda Pulmonata. J. Linn. Soc. (Zool.) v. 37 (n. ${ }^{\circ} 250$ ), p. 1-59, pl. 1-5. London.

Boettger, Caesar R. 1933, Untersuchungen über phänotypische Variationen mediterraner Napfschnecken (Patella). Pubbl. Staz. Zool. Napoli v. 12- (3), p. 337-371, pl. 5, Roma \& Berlin.

_ 1954, Die Systematik der euthyneuren Schnecken. Verh. Deut. Zool. Ges. Tübingen 1954, p. 253-280, 1 text-fig. Leipzig.

Borland, Constance 1950, Ecological study of Benhamina obliquata (Sowerby), a basommatophorous pulmonate in Otago Harbour. Trans. Pr. N. Zeal. Inst. v. 78 (4), p. 385-393, pl. 41-44. Wellington, N. Z.

Brown, Herbert H. 1934, A study of a tectibranch gasteropod mollusc, Philine aperta (L.). Trans. R. Soc. Edinb. v. 58, pt. 1 (9), p. 179-210, text-figs. 1-38. Edinburgh.

Carriker, Melbourne Romaine 1946, Morphology of the alimentary system of the snail Lymnaea stagnalis appressa Say. Trans. Wisc. Acad. Sci. v. 38, p. 1-88, pl. 1-10. Madison, Wisc.

Cooke, A. H. 1895, Molluscs. Cambridge Nat. Hist. v. 3, XI + 459 p., 311 textfigs. London (MacMillan \& Co.).

CottrelI, A. J. 1911, Anatomy of Siphonaria obliquata (Sowerby). Trans. Pr. N. Zeal. Inst. v. 43, p. 582-594, pl. 28-29. Wellington, N. Z.

Cox, L. R. 1960, Thoughts on the classification of the Gastropoda. Pr. mal. Soc. Lon. v. 33 (6), p. 239-261. London.

F.kman, Sven 1935, Tiergeographie des Meeres. XII + 542 p., 244 text-figs. Leipzig (Akad. Verlagsges.).

Farnie, Winifred Cheyne 1919, The structure of Amphibola crenata Martyn. Trans. Pr. N. Zeal. Inst. v. 51, p. 69-85, text-figs. 1-7. Wellington, N. Z.

- 1924, The development of Amphibola crenata (Martyn). Qu. Jour. micr. Sci. n. ser. v. 68 , p. 453-469, 18 text-figs. London.

Fietter, Vera \& Graham, Alastair 1949, The structure and mode of life of the Pyramidellidae, parasitic opisthobranchs. Journ. mar. biol. assoc. Unit. Kingd. v. 28, p. 493-532, text-fig. 1-12. Cambridge. 
Fretter, Vera \& Graham, Alastair 1954, Observations on the opisthobranch mollusc Acteon tornatilis (L.). Journ. mar. biol. assoc. Unit. Kingd. v. 33, p. 565-585, text-figs. 1-9. Cambridge.

Gilchrist, D. F. 1894, Beiträge zur Kenntnis der Anordnung, Correlation und Funktion der Mantelorgane der Tectibranchiata. Jen. Ztschr. Naturwiss. v. 28 , p. 408-459. Jena (not seen).

Graham, Alastair 1949, The molluscan stomach. Tr. R. Soc. Edinb. v. 61, part 3 (27), p. 737-778, 24 figs. Edinburgh \& London.

Haeckel, Werner 1911, Beiträge zur Anatomie der Gattung Chilina. Zool. Jahrb. Suppl. v. 13 (1913), Faun. Chil. v. 4, fasc. 1 (1911), p. 89-136, pl. 7-11. Jena.

Harry, Harold W. 1951, Growth changes in the shell of Pythia scarabaeus (Linné). Proc. Calif. Zool. Club, v. 2 (2), p. 7-14, text-figs. 1-10. Stanford, Cal. Hedgpeth, Joel W. 1953, An introduction to the zoogeography of the northwestern Gulf of Mexico with reference to the invertebrate fauna. Publ. Inst. Mar. Sci. v. 3 (1), p. 111-224, 46 text-figs. Texas.

Hoffmann, Hans 1940, Opisthobranchia. Bronn's K1. Ordn. v. 3, II. Abtlg. 3 . Buch, Teil 2, 90 p., 70 figs. Leipzig (Akad. Verlagsges.).

Hubendick, Bengt 1946, Systematic monograph of the Patelliformia. Kgl. Svensk. Akad. Handl. ser. 3, v. 23 (5), p. 1-93, pl. 1-6. Stockholm.

- 1947, Phylogenie und Tiergeographie der Siphonariidae. Zool. Bidr. v. 24, p. 1-216, 107 text-figs. Uppsala.

- 1950, Geographical variation of Siphonaria pectinata (L.). Atlantide Rep. n. ${ }^{\circ}$, p. 151-166, 10 text-figs. Köbenhavn.

Hutton, Frederick Wollaston 1882, Notes on the structure and development of Siphonaria australis Quoy \& Gaimard. Ann. Mag. Nat. Hist. ser. 5, v. 9 (n..$^{\circ}$ 3), p. 341-344, pl. 15. London.

Ihering, H. v. 1915, Die Opisthobranchien der brasilianischen Küste. Nachr. Bl. deut. malakol. Ges. v. 47, p. 133-143. Frankfurt a. M.

Kähler, August 1893, Beiträge zur Anatomie der Gattung Siphonaria. Zool. Jahrb. Anat. v. 7 (1), p. 1-92, pl. 1-6. Jena.

Krull, Herbert 1934, Die Aufhebung der Chiastoneurie bei den Pulmonaten. Zool. Anz. v. 105 (7-8), p. 173-182, 3 text-figs. Leipzig.

Lange de Morretes, Frederico 1949, Ensaio de catálogo dos moluscos do Brasil. Arq. Mus. Paran. v. 7 (1), p. 5-216. Curitiba (Brazil) .

Marcus, Eveline and Ernst 1957, Notes on Aplysia. Bol. Inst. Oceanogr. v. 8 (published 1959), p. 3-21, pl. 1-4. São Paulo.

Morton, J. E. 1955a, The functional morphology of Otina otis, a primitive marine pulmonate. Journ. mar. biol. assoc. Unit. Kingd. v. 34, p. 113-150, 12 text-figs. Cambridge.

- 1955b, The evolution of the Ellobiidae with a discussion on the origin of the Pulmonata. Proc. Zool. Soc. Lond. v. 125 (1), p. 127-168, 15 text-figs. London. 
1958, Molluscs. 2.32 p., 23 figs. Hutchinson University Library. London.

Pelseneer, Paul 1894, Recherches sur divers Opisthobranches. Mém. cour. Acad. Roy. Belg. (Sci. Nat.), v. 53, p. I-III, 1-15T, pl. 1-25. Bruxelles.

- 1895," "Prasobranches" aériens et Pulmonés branchifères. Arch. Bicl. v. 14, p. 351-393, 5 pl. Gand (not seen).

-1 1935, Essai d'éthologie zoologique d'après l'étude des mollusques. 662 p. Bruxelles (Académie Royale de Belgique, Classe des Sciences).

Perrier, R. et Fischer, H. 1909, Sur la cavité palléale et ses dépendences chez les Bulléens. C. R. Acad. Sci. v. 148, p. 956-959. Paris.

Perrier, R. et Fischer, H. 1910, Sur le mouvement de l'eau dans la cavité palléale et sur la structure de la branchie chez les Bulléens. C. R. Acad. Sci. v. 151, p. 102-104. Paris.

Plate, Ludwig 1897, Über primitive (Pythia scarabaeus L.) und hochgradig differenzierte (Vaginula gayi Fischer) Lungenschnecken. Verh. Deut. Zoc1. Ges., 7. Vers., Kiel, p. 119-140, text-figs. 1-5. Leipzig.

Risbec, Jean 1935, Biologie et pontes de Mollusques Gastéropodes Néo-Calédoniens. Bull. Soc. Zool. France v. 60 (5), p. 387-417, text-figs. Paris.

Schumann, W. 1911, Über die Anatomie und die systematische Stelung von Gadinia... etc. Zool. Jahrb. Suppl. v. 13 (1913), Faun. Chil. v. 4, fasc. 1 (1911), p. 1-88, pl. 1-6. Jena.

Simroth, Heinrich 1876, Ueber die Sinneswerkzeuge unserer einheimischen Weichthiere. Zeitschr. wiss. Zool. v. 26 (3), p. 227-349, pl. 15-21. Leipzig.

Simroth, Heinrich \& Hoffmann, Hans 1908-1928. Pulmonata. Bronn, Kl. Ordn. v. 3, Abt. 2, 2. Buch. 1354 p., 44 pls. Leipzig (Akad. Verlagsges.).

Smith, Edgar A. 1890, Mollusca in: H. N. Ridley, Notes on the Zoology of Fernando Ncronha. J. Linn. Soc. Lond. (Zool.) v. 20, p. 483-503, pl. 30. London.

Scuza Lcpes, Hugo \& Alvarenga, Moacir 1955, Contribuição ao conhecimento dus moluscos da ilha Fernando de Noronha, Brazil. Bol. Inst. Oceanogr. v. 6 (1-2), p. 157-196, pl. 1-3. São Paulo.

Stephenson, T. A. and Anne 1950, Life between tide-marks in North America. I. The Florida Keys. Jour. Ecol. v. 38 (2), p. 354-402. Durham, N. C.

Vcss, Gilbert L, and Nancy A. 1955, An ecological survey of Soldier Key, Biscayne Bay, Florida. Bull. mar. sci. Gulf \& Caribb. v. 5 (3), p. 203-229, 4 textfigs. Miami.

Yunge, C. M. 1947, The pallial organs in the aspidobranch Gastropoda and their evolution throughout the Mollusca. Phil. Tr. R. Soc. ser. B. (Bicl. Sci.) n. ${ }^{\circ}$ 591, v. 232, p. 443-518, 40 text-figs., pl. 18. London.

1952, The mantle cavity in Siphonaria alternata Say. Pr. mal. Soc. Lond v. 29 (5), p. 190-199, 5 text-figs. London.

1958, Observations in life of the pulmonate limpet Trimusculus (Gadinia) reticulatus (Sowerby). Pr. mal. Soc. Lond. v. 33 (1), p. 31-37, text-figs. 1-6. London. 


\section{EXPLANATION OF LETTERS OF SIPHONARIA HISPIDA}

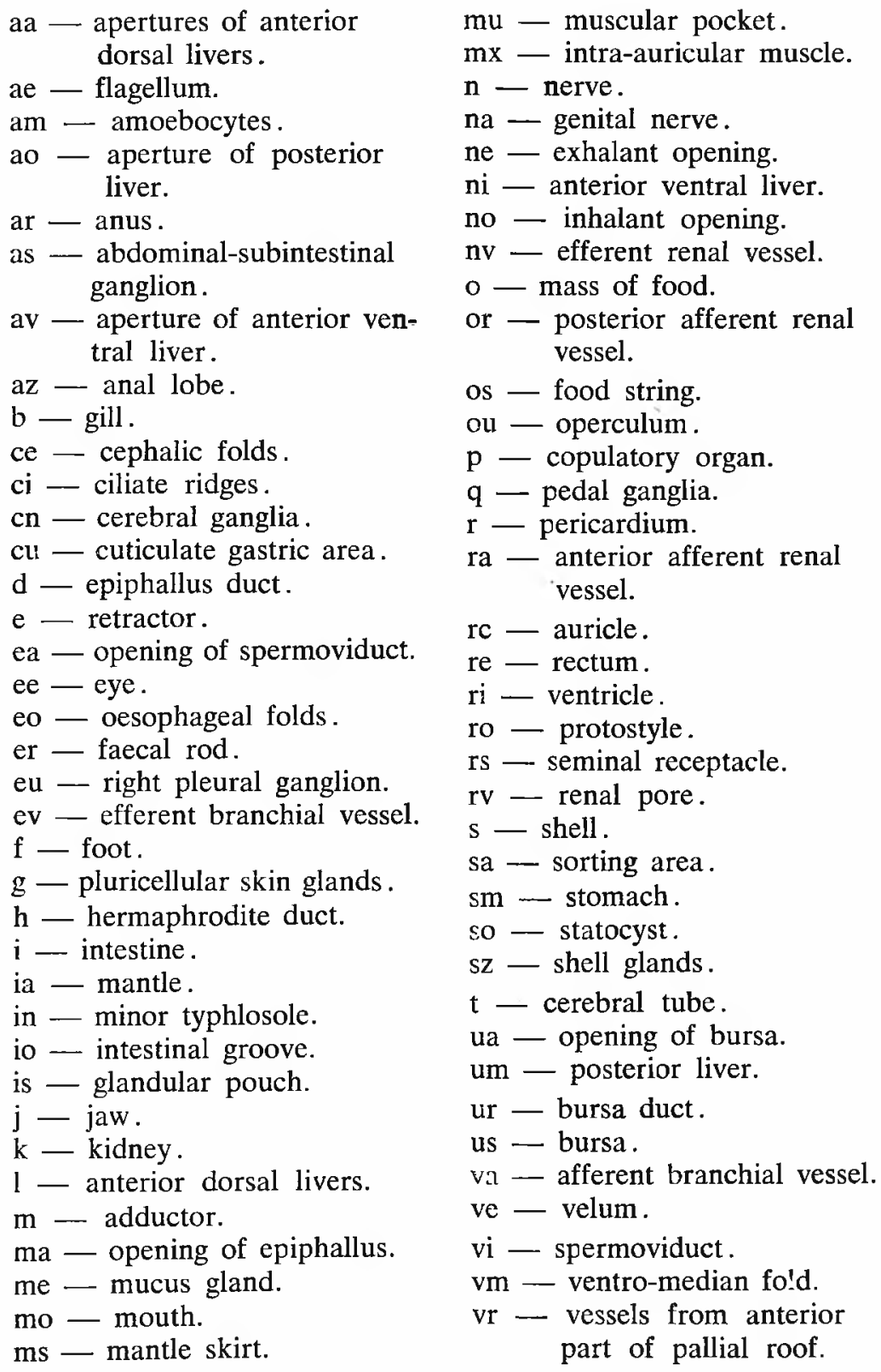
part of pallial roof. 
$\mathrm{vz}$ - efferent branchio-renal vessel.

w - glandular primordium in spermoviduct.

wa - cephalic artery.

we - albumen gland.

xo - lateral lobe of cerebral ganglion.

y - major typhlosole.

$\mathrm{z}$ - genital aperture.

wm - hermaphrodite gland. zo - osphradial ganglion.

wv $u$ - pleuro-parietal ganglion. $\quad \mathrm{zr}$ - parieto-supra-intestinal

$x$ - sense organ. ganglion.

$\mathrm{xm}$ - annular musc'es of rectum.

$\mathrm{zz}$ - glands of copulatory organ. 
P I A T E S 


\section{PLATE 1}

\section{Siphonaria hispida}

Fig. 1 - Egg string.

Fig. 2 - Part of egg string.

Fig. 3 - Three egg capsules; two with veligers, one with empty shell.

Fig. 4 - Shells of 3, 4, 5, 6, and $11 \mathrm{~mm}$ length.

Fig. 5 - Left side view of $11 \mathrm{~mm}$ shell with larval shell.

Fig. 6 - Ventral view of fore end; anterior border of foot bent downwards .

Fig. 7 - Same with evaginated copulatory organ.

Fig. 8 - Same with everted buccal cavity and partly evaginated penis. 
E. \& E. MARCUS - SIPHONARIA - PLATE 1
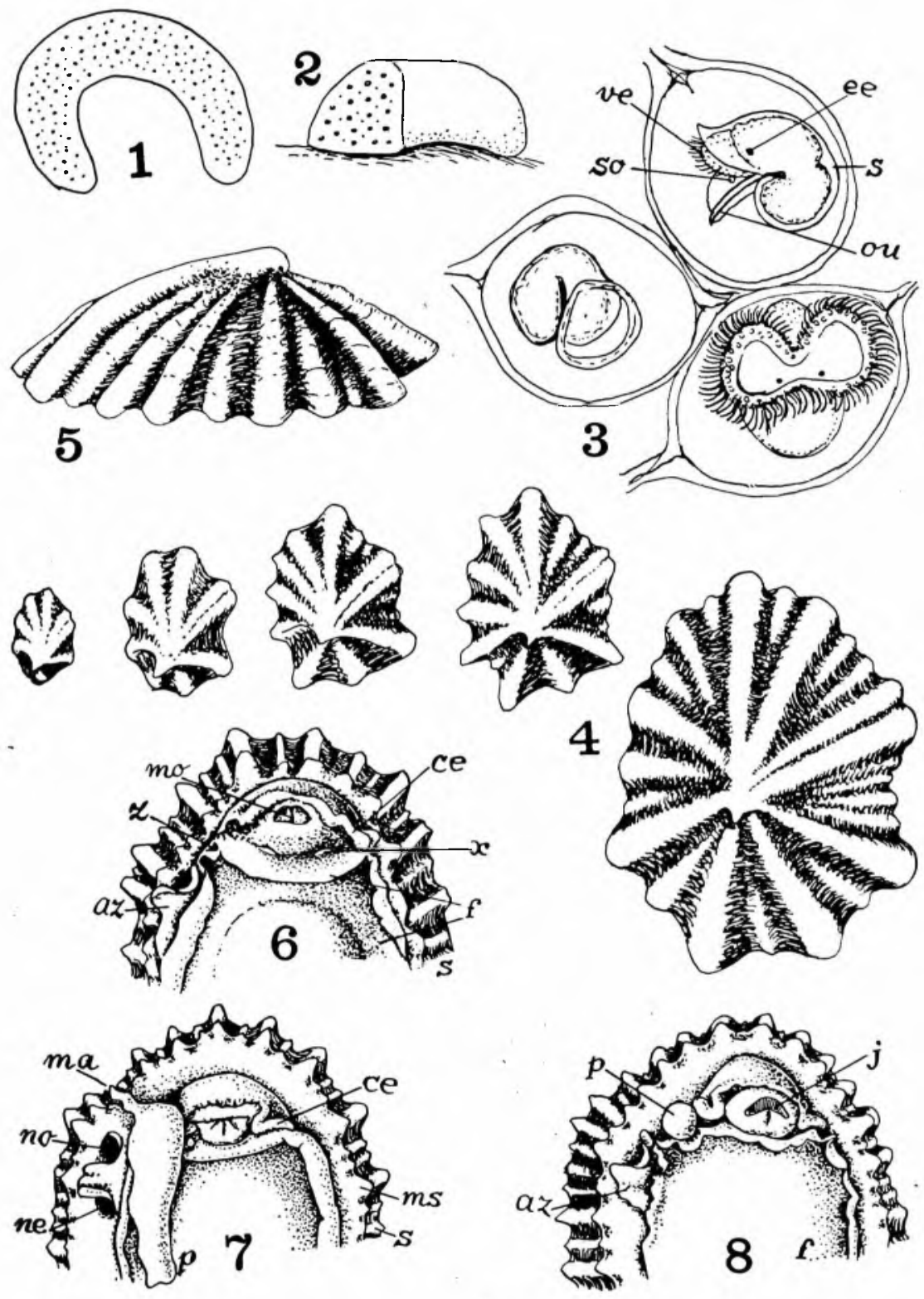


\section{PLATE 2}

\section{Siphonaria hispida}

Fig. $9-$ Roof of pallial cavity.

Fig. 10 - Tangential section of pallial cavity .

Fig. 11 - Right side of transverse section of snail.

Fig. 12 - Transverse section of left cerebral tube. 
E. \& E. MARCUS - SIPHONARIA - PLATE 2

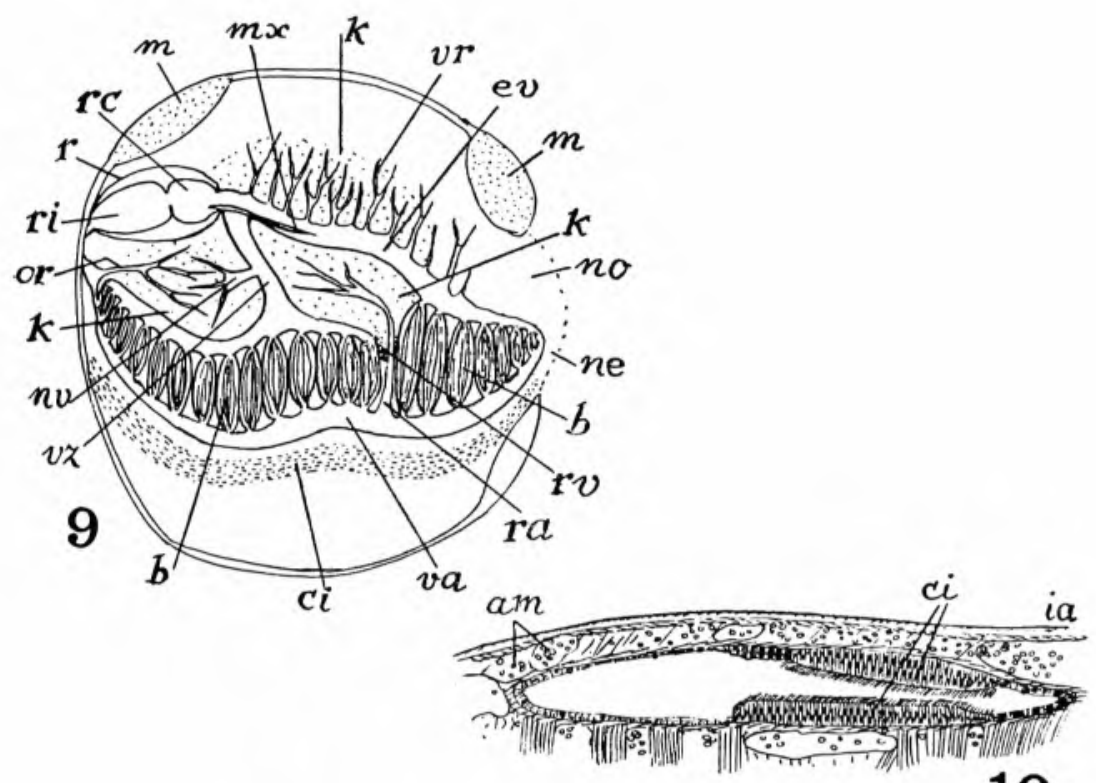

10

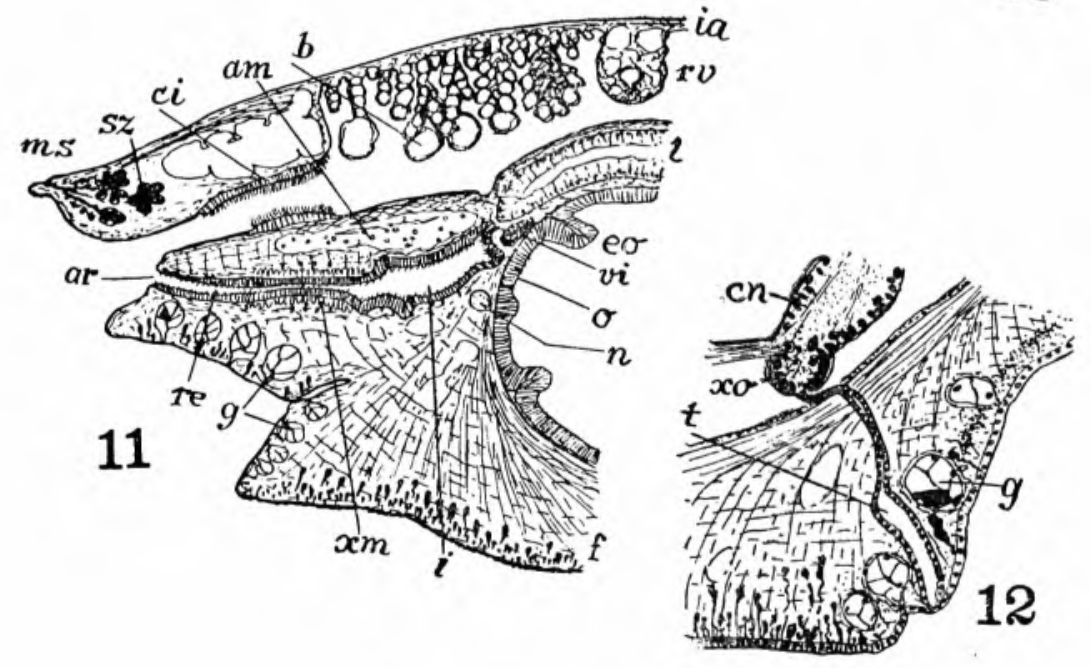




\section{PLATE 3}

\section{Siphonaria hispida}

Fig. 13 - Central nervous system.

Fig. 14 - Radula of $4 \mathrm{~mm}$ long snail.

Fig. 15 - Same of adult snail.

Fig. 16 - Alimentary organs.

Fig. 17 - Stomach of preserved snail opened from the dorsal side; broad trace indicates cuts. Food string and protostyle from life. 
E. \& E. MARCUS - SIPHONARIA - PLATE 3

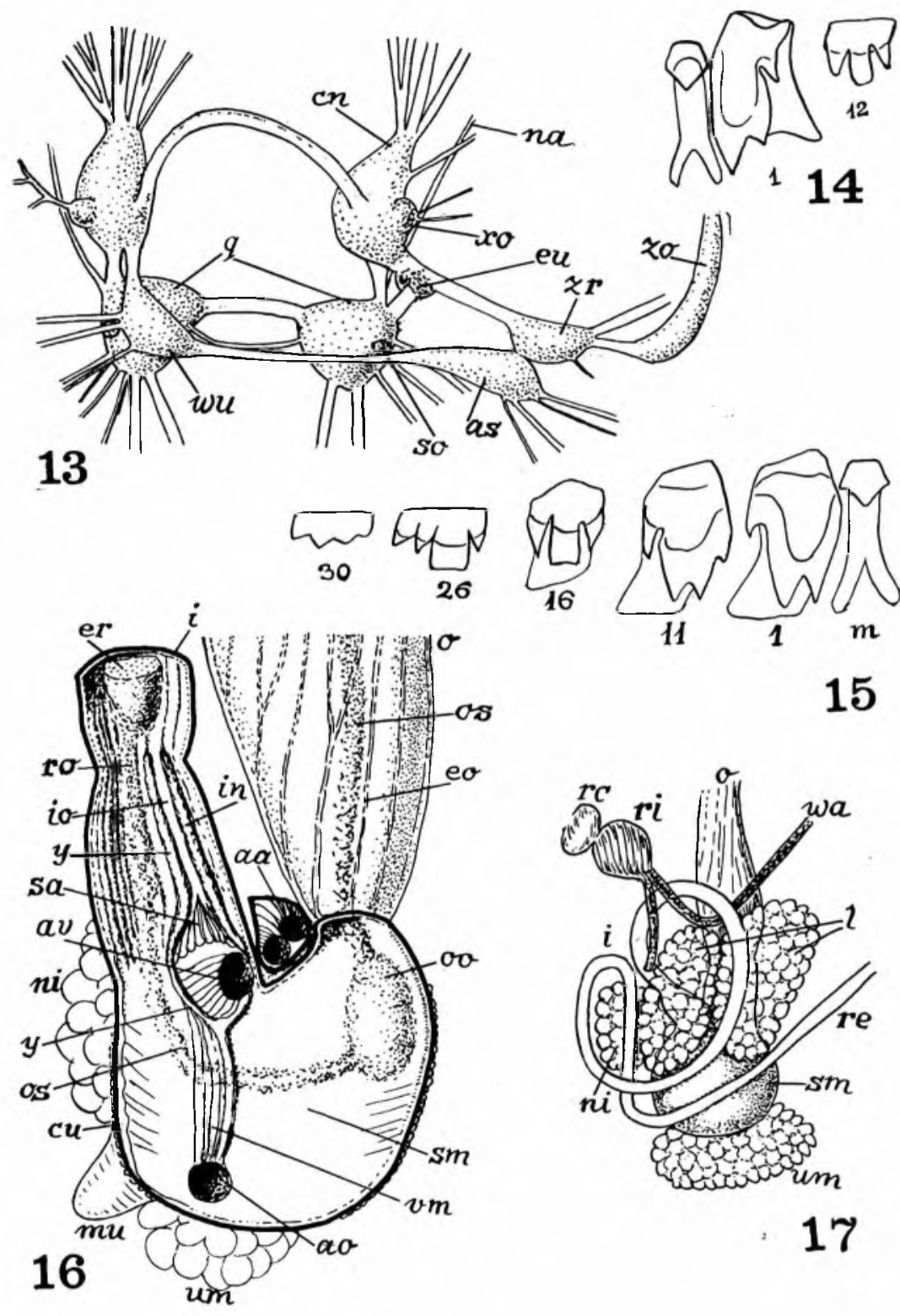




\section{PLATE 4}

\section{Siphonaria hispida}

Fig. 18 - Reproductive organs .

Fig. 19 - Transverse sections of invaginated and evaginated copulatory organ; same scale.

Fig. $20-$ Combined transverse section of evaginated distal genital organs.

Fig. 21 - Primordial genital duct of $1,8 \mathrm{~mm}$ long snail.

Fig. 22 - Same of $2 \mathrm{~mm}$ long snail. 
E. \& E. MARCUS - SIPHONARIA - PLATE 4
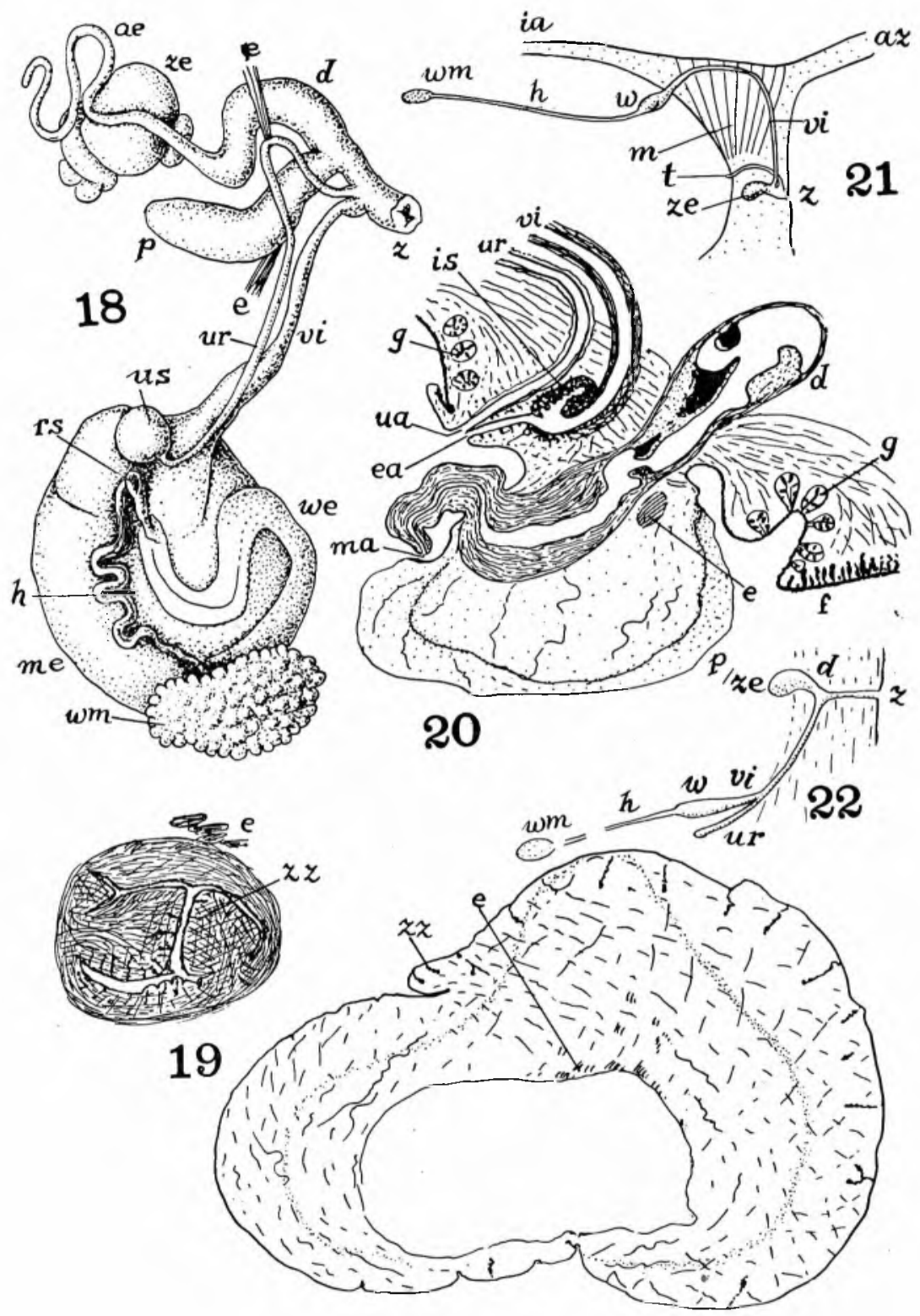
